\title{
Kajian Formulasi dan Karakterisasi Self-nanoemulsifying Drug Delivery System (SNEDDS) sebagai Penghantar Agen Antihiperlipidemia Oral
}

\author{
Dyah Ayu Nurismawati *, Sani Ega Priani \\ Prodi Farmasi, Fakultas Matematika dan Ilmu Pengetahuan Alam, \\ Universitas Islam Bandung, Indonesia. \\ *dyahayu.risma@gmail.com, egapriani@gmail.com
}

\begin{abstract}
Hyperlipidemia is one of the risk factors of various cardiovascular diseases. Several oral antihyperlipidemic agents are known to belong to BCS class II where the active substance has low solubility in water so that it has the impact of low production of dissolution profile and pharmacological effects. One of the delivery systems that can improve the solubility of hydrophobic pharmaceutical active substances is SNEDDS (Self-nanoemulsifying Drug Delivery System). This literature study aims to determine the SNEDDS formulation and its characteristics. The method used is the systematic literature review which consists of a series of stages including designing, searching, retrieving, selecting, and determining articles based on inclusion criteria. Several active substances that formulated into SNEDDS consisted of rosuvastatin, atorvastatin, ezetimibe, gemfibrozil, and perillaldehyde. Different compositions in each SNEDDS formula provide a various characteristic (particle size, polydispersity index, zeta potential value, and emulsification time) of the resulting nanoemulsion. The best formula is ezetimibe-loaded SNEDDS with a particle size of $54,07 \mathrm{~nm}$; zeta potential of $-38,76 \mathrm{mV}$; and emulsification time of 0,6 second.
\end{abstract}

Keywords: Development, SNEDDS, Oral antihyperlipidemic, BCS class II.

\begin{abstract}
Abstrak. Hiperlipidemia merupakan salah satu faktor resiko penyebab berbagai penyakit kardiovaskular. Diketahui beberapa agen antihiperlipidemia oral termasuk ke dalam BCS kelas II dimana zat aktif memiliki kelarutan yang rendah dalam air sehingga berdampak pada rendahnya profil disolusi dan efek farmakologi yang dihasilkan. Self-nanoemulsifying Drug Delivery System (SNEDDS) merupakan salah satu sistem penghantaran yang mampu memperbaiki kelarutan zat aktif farmasi hidrofobik. Studi literatur ini bertujuan untuk mengetahui formulasi SNEDDS dan karakteristiknya. Metode yang digunakan yaitu systematic literature review yang terdiri atas serangkaian tahap meliputi perancangan, pencarian, pengambilan, seleksi, dan penentuan artikel berdasarkan kriteria inklusi. Beberapa senyawa aktif yang diformulasikan menjadi SNEDDS terdiri dari rosuvastatin, atorvastatin, ezetimib, gemfibrozil, dan perillaldehyde. Komponen bahan yang berbeda dalam setiap formula menghasilkan variasi karakteristik (ukuran partikel, indeks polidispersitas, nilai zeta potensial, dan waktu emulsifikasi) nanoemulsi yang dihasilkan. Formula yang paling memenuhi kriteria adalah SNEDDS ezetimibe dengan ukuran partikel 54,07 nm; nilai zeta potensial $-38,76 \mathrm{mV}$; dan waktu emulsifikasi 0,6 detik.
\end{abstract}

Kata Kunci: Pengembangan, SNEDDS, Antihiperlipidemia oral, BCS kelas II. 


\section{A. Pendahuluan}

Hiperlipidemia adalah suatu kondisi dimana terjadi peningkatan kadar lemak dan atau lipoprotein yang melebihi batas normal (Gupta et al., 2011). Kondisi kelebihan lemak dalam sirkulasi darah ini dapat disebut juga dengan hiperlipoproteinemia karena substansi lemak yang mengalir di peredaran darah terikat oleh protein sebab lemak merupakan partikel yang tidak larut air. Klasifikasi hiperlipidemia berdasarkan etiologinya dibedakan menjadi tiga, yaitu hiperlipidemia primer yang disebabkan karena kelainan genetik spesifik; hiperlipidemia sekunder yang terjadi karena gaya hidup atau penyakit lain sehingga menyebabkan kelainan metabolisme lemak dan lipoprotein; serta hiperlipidemia idiopatik yang belum diketahui secara pasti penyebabnya (Harikumar et al., 2013). Hiperlipidemia terbukti menjadi penyebab beberapa penyakit kronis seperti penyakit jantung koroner (PJK), stroke, aterosklerosis, dan pankreatitis (Gupta et al., 2011; Bhatnagar et al., 2008).

Penggunaan obat menjadi sangat penting untuk mengatasi kondisi hiperlipidemia. Beberapa zat aktif yang digunakan sebagai antihiperlipidemia termasuk ke dalam BCS (Biopharmaceutical Classification System) kelas II. Obat-obat tersebut memiliki kelarutan yang rendah dalam air sehingga mempengaruhi kemampuan disolusi dan menghasilkan bioavailabilitas yang rendah (Kasim et al., 2004). Salah satu sistem penghantaran obat secara oral yaitu SNEDDS (Self-nano Emulsifying Drug Delivery System). Self-nanoemulsifying Drug Delivery System (SNEDDS) merupakan salah satu sistem nanoteknologi berbasis minyak. SNEDDS adalah campuran isotropik antara minyak, surfaktan, dan kosurfaktan yang dapat membentuk nanoemulsi secara spontan ketika kontak dengan cairan lambung disertai agitasi ringan (Makadia et al., 2013).

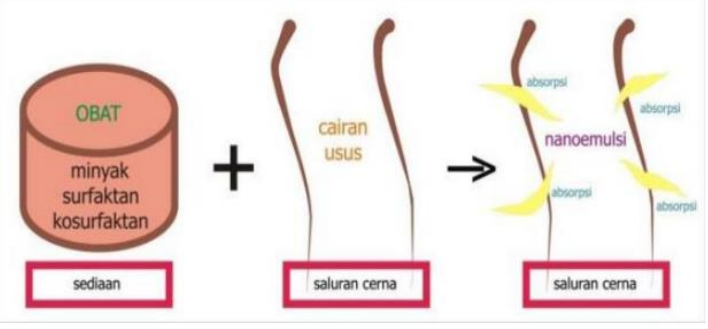

Gambar 1. Konsep Pembentukan SNEDDS (Martien et al., 2012)

SNEDDS juga diketahui sebagai bentuk anhidrat atau prekonsentrat dari nanoemulsi, hal ini dikarenakan SNEDDS tidak mengandung air. Komponen air yang diperlukan dalam pembentukan nanoemulsi akan diperoleh ketika SNEDDS mencapai saluran cerna (cairan lambung). Jenis nanoemulsi yang terbentuk secara spontan adalah emulsi minyak dalam air (M/A) dengan ukuran globul tidak lebih dari $100 \mathrm{~nm}$ (Singh et al., 2009). seperti:

Bila dibandingkan dengan nanoemulsi biasa, SNEDDS memiliki beberapa kelebihan

1. Lebih stabil secara fisikokimia ketika dalam masa simpan (karena tidak mengandung komponen air).

2. Dapat ditransformasi menjadi berbagai bentuk sediaan seperti kapsul (soft/hard gelatin atau HPMC), kelebihan ini dapat meningkatkan daya komersil dan penerimaan pasien terhadap obat.

3. Mudah dalam pembuatannya

Formulasi SNEDDS bertujuan untuk meningkatkan kemampuan disolusi dari zat aktif dengan cara memfasilitasi pembentukan fasa tersolubilisasi dan meningkatkan transpor melalui sistem limfatik usus, serta menghindari effluks P- $g p$, sehingga dapat meningkatkan absorpsi dan bioavailabilitas zat aktif dari saluran cerna (Singh et al., 2009).

Berdasarkan pemaparan di atas, rumusan masalah penelitian ini adalah bagaimana formulasi SNEDDS mengandung agen antihiperlipidemia serta bagaimana karakteristiknya. 
Tujuan dari penelitian ini adalah untuk memperoleh formula SNEDDS mengandung agen antihiperlipidemia dengan karakteristik yang baik.

\section{B. Metodologi Penelitian}

Jenis penelitian yang dilakukan adalah Systematic Literatur Review (SLR) dengan mengidentifikasi, menganalisis, serta mengintepretasikan seluruh hasil temuan ke dalam penelitian. Beberapa tahapan dalam studi literatur diantaranya adalah perancangan (planning), pencarian dan pengambilan (searching and retrieval), seleksi artikel (filtering and sorting), penentuan artikel (final inclusion), mengekstrak data (data extraction and syntesis), hingga pelaporan hasil review (reporting).

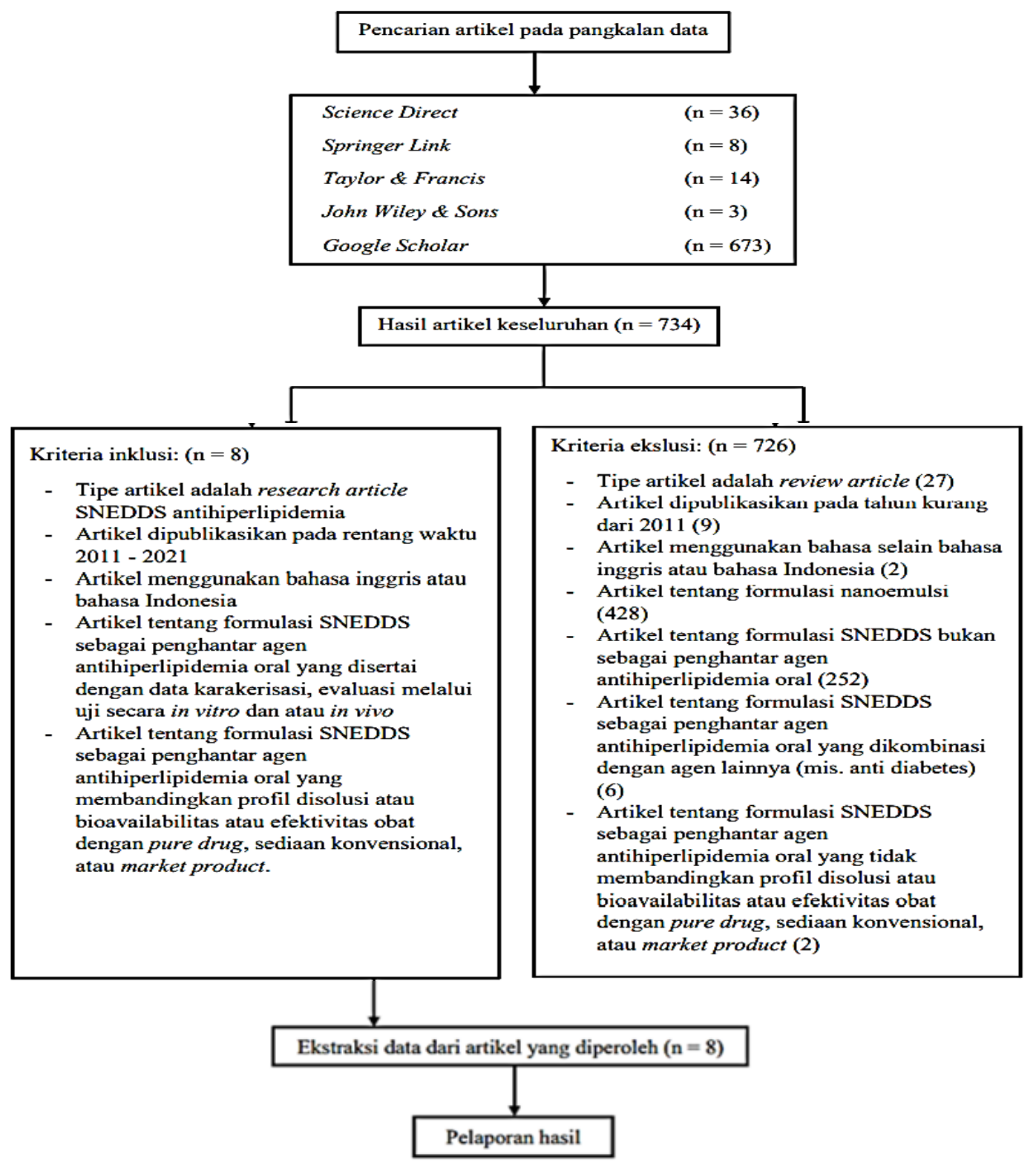

Gambar 2. Diagram alur penelitian

Tahap pertama yang dilakukan pada penelitian ini adalah perancangan topik serta tujuan dari penelitian. Selanjutnya dilakukan pencarian dan pengambilan artikel yang dipublikasikan oleh penerbit baik nasional maupun internasional pada situs Science Direct (Elsevier), Taylor and Francis, Springer, dan Google Scholar. Proses pencarian artikel 
menggunakan key words atau kata kunci, yakni self nanoemulsifying drug delivery system, SNEDDS, dan hyperlipidemia. Setelah diperoleh artikel yang berkaitan dengan topik penelitian, maka tahap selanjutnya adalah seleksi artikel dengan merancang kriteria inklusi dan eksklusi. Artikel terpilih ditentukan oleh kesesuaiannya dengan kriteria inklusi yang telah ditetapkan (Gambar 2).

Tahap berikutnya yaitu dilakukan ekstraksi data yang berkaitan dengan topik penelitian. Hasil dari ekstraksi data kemudian dilanjutkan dengan pelaporan hasil studi literatur pada draft penelitian berupa formulasi dan karakterisasi SNEDDS mengandung agen antihiperlipidemia oral.

\section{Hasil Penelitian dan Pembahasan}

Berdasarkan Tabel 1 terlihat bahwa semua zat aktif diformulasikan ke dalam SNEDDS dengan menggunakan komponen minyak, surfaktan, dan kosurfaktan. Jenis minyak, surfaktan, dan kosurfaktan yang digunakan berbeda-beda untuk setiap zat aktif. Minyak digunakan sebagai fase pendispersi atau melarutkan zat aktif yang bersifat lipofil. Komponen minyak atau fase minyak berperan penting dalam formulasi SNEDDS. Kepolaran dan viskositas fase minyak merupakan karakteristik fisikokimia salah satu komponen SNEDDS yang akan sangat mempengaruhi formula dalam beberapa hal yaitu kelarutan obat dalam sistem, kemampuan untuk membentuk nanoemulsi secara spontan, dan ukuran tetesan nanoemulsi. Konsentrasi dan lipofilisitas fase minyak dalam SNEDDS proporsional terhadap ukuran tetesan nanoemulsi yang dihasilkan (Makadia et al., 2013). Minyak yang digunakan dalam formulasi SNEDDS tersebut yaitu perilla frutescens oil, peceol, asam oleat, capryol 90, lemonessential oil, kombinasi isopropyl myristate dan medium chain triglyceride. Minyakminyak tersebut berasal dari golongan asam lemak, gliserida rantai sedang hingga panjang, dan minyak esensial (Date et al., 2010). Minyak tersebut dipilih dan digunakan dalam formulasi SNEDDS berdasarkan pada kemampuan yang paling baik dalam melarutkan zat aktif.

Mengingat minyak sebagai pembawa utama zat aktif dalam SNEDDS, sehingga kemampuan minyak untuk melarutkan zat aktif dengan baik menentukan kapasitas zat aktif yang dapat dibawa. Selain itu, kelarutan zat aktif dalam pembawanya dapat mencegah pengendapan obat ketika terdilusi oleh cairan saluran cerna (Pouton, 2006).

Komponen bahan selanjutnya yaitu surfaktan. Surfaktan adalah zat yang dalam struktur molekulnya memiliki bagian lipofil dan hidrofil yang berfungsi untuk menurunkan tegangan antar muka antara dua zat yang tidak saling bercampur, dalam hal ini adalah minyak dan air. Berbeda halnya dengan minyak, selain kemampuan melarutkan zat aktif, penggunaan surfaktan dalam formulasi SNEDDS memerhatikan nilai HLB (Hydrophylic-Lipophylic Balance) (Singh et al., 2009). Pertimbangan dalam menentukan surfaktan yang akan digunakan dalam formulasi SNEDDS adalah jenis surfaktan dan tipe emulsi yang akan dihasilkan.

SNEDDS merupakan sistem penghantaran yang ditujukan untuk membentuk nanoemulsi secara spontan dengan tipe emulsi minyak dalam air. Untuk memperoleh tipe emulsi minyak dalam air, diperlukan surfaktan dengan nilai HLB lebih dari 10 dengan jenis surfaktan non-ionik (Debnath et al., 2011). Surfaktan non-ionik lebih banyak digunakan dibandingkan surfaktan jenis lain, khususnya dalam formulasi sediaan rute oral. Hal ini dikarenakan sifat dari surfaktan non-ionik yang biokompatibel, aman, dan kondisi pH tertentu tidak terlalu mempengaruhi kinerjanya (Azeem et al., 2009).

Berdasarkan Tabel 1 terlihat bahwa surfaktan yang digunakan dalam formulasi SNEDDS yaitu Cremophor EL, Cremophor RH 40, Tween 80, dan Labrasol. Beberapa surfaktan tersebut memiliki nilai HLB pada kisaran 12-16. Surfaktan dengan nilai HLB pada rentang tersebut memiliki sifat yang cenderung hidrofil. Surfaktan dengan hidrofilisitas yang cukup tinggi diperlukan dalam formulasi SNEDDS karena sifatnya yang dapat membentuk self-emulsifikasi secara spontan, menyebar dengan cepat dalam media air, sehingga dapat menjaga obat untuk tetap di tempat penyerapan dan mencegah pengendapan senyawa obat dalam saluran cerna (Singh et al., 2009). 
Tween 80 merupakan salah satu contoh surfaktan hidrofilik yang paling banyak digunakan dalam formulasi berbagai jenis emulsi tipe minyak dalam air. Sementara dalam artikel yang ditulis oleh Jeetendra Singh Negi (2019), dijelaskan bahwa Cremophor EL dapat menghasilkan ukuran globul yang sangat kecil. Hal tersebut didukung oleh struktur kimia bercabang pada Cremophor EL sehingga mampu meningkatkan fleksibilitas antarmuka. Bahkan kemampuan Cremophor EL dalam mereduksi ukuran globul dianggap lebih baik dibandingkan Tween 80. Dalam artikel yang sama, dijelaskan juga bahwa Labrasol banyak digunakan sebagai surfaktan dalam formulasi SNEDDS karena memiliki daya larut yang baik. Labrasol juga mampu meningkatkan fluiditas lipid membran dan permeabilitas membran berbagai zat aktif farmasi.

Komponen bahan berikutnya adalah kosurfaktan yang berfungsi untuk membantu surfaktan dalam menurunkan tegangan antar muka dengan perluasan lapisan film (globul). Penggunaan kosurfaktan pada SNEDDS bertujuan untuk meningkatkan drug loading, mempercepat self-emulsification, dan mengatur ukuran droplet nanoemulsi (Date et al., 2010). Senyawa amfifilik kosurfaktan memiliki afinitas terhadap air dan minyak. Secara umum, kosurfaktan yang dipilih berupa alkohol rantai pendek karena mampu mengurangi tegangan antarmuka, meningkatkan fluiditas antarmuka, dan mampu meningkatkan pencampuran air dan minyak karena partisinya diantara dua fase tersebut (Azeem et al., 2009). Seperti halnya kriteria dalam memilih surfaktan, dalam memilih kosurfaktan khususnya untuk sediaan oral harus dengan pertimbangan sifat kosurfaktan yang tidak toksik dan tidak mengiritasi (Rowe $e t$ al., 2009).

Sebagaimana yang terlampir pada Tabel 1 kosurfaktan yang digunakan dalam pengembangan formula SNEDDS yaitu propilen glikol monolaurat, transcutol HP, propilen glikol, polietilen glikol 400, Capmul MCM-C8, dan polietilen glikol 200. Beberapa kosurfaktan tersebut berasal dari golongan alkohol rantai pendek, glikol eter, alkanol, dan polietilen glikol (Date et al., 2010). Dasar pertimbangan dalam pemilihan kosurfaktan adalah kemampuan dalam melarutkan zat aktif, ketercampuran dengan komponen bahan lain, serta sifat biokompatibel dan nonirritant ketika digunakan secara per oral.

Setelah memperoleh komponen bahan apa saja yang digunakan dalam formulasi SNEDDS, kemudian melalui tahap pembuatan, maka tahapan selanjutnya adalah evaluasi dan karakterisasi. Karakterisasi SNEDDS bertujuan untuk mengetahui karakteristik nanoemulsi yang dihasilkan, sehingga sebelum dilakukan karakterisasi harus dilakukan pengencaran terlebih dahulu terhadap SNEDDS. 
Kajian Formulasi dan Karakterisasi Self-nanoemulsifying Drug Delivery System (SNEDDS)...| 119

Tabel 1. Formulasi SNEDDS 
120 | Dyah Ayu Nurismawati, et al.

\begin{tabular}{|c|c|c|c|}
\hline Zat Aktif & Formula & Karakteristik & Pustaka \\
\hline \multirow{6}{*}{ Rosuvastatin } & $\begin{array}{l}\text { Minyak: Perilla } \\
\text { frutescens oil }\end{array}$ & $\begin{array}{l}\text { Ukuran partikel: } \\
17,9 \mathrm{~nm}\end{array}$ & $\begin{array}{l}\text { Tripathi et al = } \\
2017\end{array}$ \\
\hline & $\begin{array}{l}\text { Surfaktan: Cremophor } \\
\text { EL }\end{array}$ & $\begin{array}{l}\text { Zeta potensial : } \\
21 \mathrm{mV}\end{array}$ & \\
\hline & $\begin{array}{l}\text { Kosurfaktan: Propilen } \\
\text { gliko1 monolaurat }\end{array}$ & $\begin{array}{l}\text { Waktu emulsifika si : } \\
120 \text { detik }\end{array}$ & \\
\hline & $\begin{array}{l}\text { Minyak: Peceol } \\
\text { S urfaktan: Tween } 80\end{array}$ & $\begin{array}{l}\text { Ukuran partikel: } \\
36,5 \mathrm{~nm}\end{array}$ & Beget al., 2017 \\
\hline & $\begin{array}{l}\text { Kosurfaktan: Transcuto } 1 \\
\text { HP }\end{array}$ & $\begin{array}{l}\text { Zeta potensial: } \\
-11,2 \mathrm{mV}\end{array}$ & \\
\hline & & $\begin{array}{l}\text { Waktu emulsi fika si : } \\
131 \text { detik }\end{array}$ & \\
\hline \multirow{6}{*}{ Atorvastatin } & Minyak: A sam oleat & $\begin{array}{l}\text { Ukuran partikel: } \\
73,5 \mathrm{~nm}\end{array}$ & $\begin{array}{l}\text { Hashem et al }= \\
2015\end{array}$ \\
\hline & $\begin{array}{l}\text { Surfaktan: Tween } 80 \\
\text { Kosurfaktan: Propilen } \\
\text { gliko1 }\end{array}$ & $\begin{array}{l}\text { Zeta potensial: } \\
-24,1 \mathrm{mV}\end{array}$ & \\
\hline & $\begin{array}{l}\text { Minyak: Cap ry o1 } 90 \\
\text { Surfaktan: Tween } 80 \text {, } \\
\text { Cremophor RH } 40\end{array}$ & $\begin{array}{l}\text { Ukuran partikel: } \\
101,3 \mathrm{~nm}\end{array}$ & $\begin{array}{l}\text { Gardouh et al := } \\
2020\end{array}$ \\
\hline & $\begin{array}{l}\text { Kosurfaktan: Transcutol } \\
\text { HP }\end{array}$ & PDI: 0,241 & \\
\hline & & Zeta potensial: $-23 \mathrm{mV}$ & \\
\hline & & $\begin{array}{l}\text { Waktu emulsi fika si : } \\
<60 \text { detik }\end{array}$ & \\
\hline \multirow{11}{*}{ Ezetimib } & Minyak: Cap ry o1 90 & $\begin{array}{l}\text { Ukuran partikel: } \\
101,3 \mathrm{~nm}\end{array}$ & $\begin{array}{l}\text { Gardouh et al -, } \\
2020\end{array}$ \\
\hline & $\begin{array}{l}\text { Surfaktan: Tween } 80, \\
\text { Cremophor RH } 40\end{array}$ & PDI: 0,241 & \\
\hline & $\begin{array}{l}\text { Kosurfaktan: Transcutol } \\
\text { HP }\end{array}$ & Zeta potensial: $-23 \mathrm{mV}$ & \\
\hline & & Waktu Emu lsi fikasi: & \\
\hline & & $<60$ detik & \\
\hline & Minyak: Maisine $35-1$ & $\begin{array}{l}\text { Ukuran partikel: } \\
54,07 \mathrm{~nm}\end{array}$ & $\begin{array}{l}\text { Bandyopadhy ay } \\
\text { et al },, 2012\end{array}$ \\
\hline & S urfaktan: L abrasol & $\begin{array}{l}\text { Zeta potensial: } \\
-38,76 \mathrm{mV}\end{array}$ & \\
\hline & & $\begin{array}{l}\text { Waktu emulsifika si : } \\
0,6 \text { detik }\end{array}$ & \\
\hline & Minyak: A sam Oleat & $\begin{array}{l}\text { Ukuran partikel: } \\
90,63 \mathrm{~nm}\end{array}$ & $\begin{array}{l}\text { Dabhi et al }= \\
2011\end{array}$ \\
\hline & S urfaktan: Tween- 80 & $\begin{array}{l}\text { Zeta potensial: } \\
0,95 \mathrm{mV}\end{array}$ & \\
\hline & Kosurfaktan: PEG 400 & $\begin{array}{l}\text { Waktu emulsifika si : } \\
20 \text { detik }\end{array}$ & \\
\hline \multirow[t]{2}{*}{ Gemfibrozil } & $\begin{array}{l}\text { Minyak: Lemon essential } \\
\text { oi1 }\end{array}$ & $\begin{array}{l}\text { Ukuran partikel: } 56,5 \\
\text { nm }\end{array}$ & Villar et al ., 2012 \\
\hline & $\begin{array}{l}\text { Surfaktan: Cremophor } \\
\text { EL } \\
\text { Kosurfaktan: Capmul } \\
\text { M CM-C8 }\end{array}$ & & \\
\hline \multirow[t]{3}{*}{ Perillaldehyde } & $\begin{array}{l}\text { Minyak: Isopropy } 1 \\
\text { myristate, medium chain } \\
\text { triglyceride }\end{array}$ & $\begin{array}{l}\text { Ukuran partikel: } \\
32,8 \mathrm{~nm}\end{array}$ & Siaw et al ., 2016 \\
\hline & $\begin{array}{l}\text { Surfaktan: Cremophor } \\
\text { EL, }\end{array}$ & PDI: 0,27 & \\
\hline & Kosurfaktan: PEG 200 & $\begin{array}{l}\text { Zeta potensial: } \\
10,14\end{array}$ & \\
\hline
\end{tabular}

Pada penelitian ini, karakteristik SNEDDS yang dikaji adalah ukuran partikel, indeks polidispersitas, zeta potensial, dan waktu emulsifikasi. Berdasarkan studi literatur yang telah 
dilakukan, diperoleh hasil bahwa ukuran partikel SNEDDS berada pada rentang 17,9 - 101,3 $\mathrm{nm}$. Secara umum ukuran partikel yang dihasilkan sudah memenuhi persyaratan $(<100 \mathrm{~nm})$ (Singh et al., 2009), namun terdapat beberapa jurnal yang menunjukkan ukuran partikel sedikit melebihi kriteria, yaitu formula SNEDDS atorvastatin dan ezetimib (Gardouh et al., 2020).

Berbeda dengan ukuran partikel, karakterisasi indeks polidispersitas hanya diuji pada tiga penelitian (Gardouh et al., 2020; Villar et al., 2012; Siaw et al., 2016). Indeks polidispersitas diuji untuk mengetahui keseragaman ukuran partikel/globul. Hasil yang diperoleh dari ketiga artikel yang telah disebutkan yaitu 0,241,0,26, 0,27. Hasil tersebut masuk ke dalam rentang nilai Indeks Polidispersitas/Polidispersity Index (PDI) yang dapat diterima dengan baik yaitu antara 0 (partikel monodispersi) hingga 0,5 (distribusi ukuran partikel besar) (Adi et al., 2019).

Karakterisasi selanjutnya yaitu penentuan nilai zeta potensial yang bertujuan untuk mengetahui stabilitas koloid atau stabilitas fisik nanoemulsi. Nilai zeta potensial menunjukkan muatan permukaan globul nanoemulsi yang terbentuk, muatan yang sama akan memberikan gaya tolak menolak antar globul sehingga mencegah terjadinya flokulasi (penggabungan globul-globul kecil membentuk globul yang lebih besar). Nilai zeta potensial yang ideal harus kurang dari $-30 \mathrm{mV}$ atau lebih dari $+30 \mathrm{mV}$, menandakan bahwa semakin negatif atau semakin positif muatan permukaan globul maka semakin stabil sistem dispersi yang terbentuk (Akhtar et al., 2012). Sementara hasil yang diperoleh dari beberapa penelitian yang dikaji menunjukkan nilai zeta potensial $-24,-23,-11,-10,14,0,95,21$, hingga $38 \mathrm{mV}$.

Beberapa nilai zeta potensial yang diperoleh tidak memenuhi kriteria sehingga rentan mengalami flokulasi. Oleh karena itu harus dilakukan pengujian lebih lanjut untuk memastikan stabilitasnya. Sementara nilai zeta potensial yang lainnya mendekati kriteria, seperti pada formula SNEDDS rosuvastatin (Tripathi et al., 2017), SNEDDS atorvastatin dan ezetimib (Hashem et al., 2015; Gardouh et al., 2020). Sementara yang paling memenuhi kriteria adalah formula SNEDDS ezetimib (Bandyopadhyay et al., 2012)

Selanjutnya dilakukan pengujian terhadap waktu emulsifikasi. Pengujian waktu emulsifikasi penting dilakukan untuk melihat kemampuan SNEDDS membentuk nanoemulsi dengan sendirinya. Pengujian waktu emulsifikasi menjadi gambaran seberapa baik surfaktan dan kosurfaktan membentuk lapisan antar muka minyak dan air dengan energi rendah (agitasi ringan) di saluran cerna, sehingga sebelum SNEDDS masuk ke dalam saluran cerna, pengujian dapat dilakukan secara in vitro dengan media yang disesuaikan (Wahyuningsih dan Widyasari, 2015). Hasil yang diperoleh menunjukkan bahwa formula SNEDDS dapat melakukan selfemulsifikasi dalam rentang waktu 0,6 - 131 detik. Menurut Kaur et al (2013), formula SNEDDS dikatakan baik apabila waktu emulsifikasi yang diperlukan kurang dari 2 menit. Berdasarkan karakteristik beberapa formula SNEDDS yang dikaji, dapat diketahui bahwa terdapat formula dengan karakteristik yang kurang sesuai kriteria, yaitu formula SNEDDS rosuvastatin (Beg et al., 2017).

Berdasarkan hasil karakterisasi formula SNEDDS, dapat disimpulkan bahwa formula yang paling memenuhi kriteria adalah SNEDDS ezetimibe dengan ukuran partikel 54,07 nm; nilai zeta potensial $-38,76 \mathrm{mV}$; dan waktu emulsifikasi 0,6 detik (Bandyopadhyay et al., 2012).

\section{Kesimpulan}

Self-nanoemulsifying Drug Delivery System (SNEDDS) adalah campuran isotropik antara minyak, surfaktan, dan kosurfaktan yang dapat membentuk nanoemulsi secara spontan ketika kontak dengan cairan lambung disertai agitasi ringan. Formulasi SNEDDS dengan komponen bahan berbeda menghasilkan variasi karakteristik nanoemulsi. Formula yang paling memenuhi kriteria adalah SNEDDS ezetimibe dengan ukuran partikel 54,07 nm; nilai zeta potensial $38,76 \mathrm{mV}$; dan waktu emulsifikasi 0,6 detik.

\section{Acknowledge}

Penulis mengucapkan banyak terima kasih kepada Ibu apt. Sani Ega Priani, M.Si. 
selaku dosen pembimbing utama dan Ibu apt. Fitrianti Darusman, M.Si. selaku dosen pembimbing serta yang telah mendukung dan membimbing penulis dalam proses penelitian, penyusunan, hingga penulisan artikel ini. Penulis juga mengucapkan banyak terima kasih kepada teman-teman yang telah membantu dan saling memberi dukungan tanpa pamrih selama proses penyusunan artikel.

\section{Daftar Pustaka}

[1] Adi, A. C., Setiawaty, N., Anindya, A. L., \& Dan Karakterisasi Sediaan Nanoemulsi Vitamin 1-3.

[2] Akhtar, F., Rizvi, M. M., \& Kar, S. K. (2012). Oral delivery of curcumin bound to chitosan nanoparticles cured Plasmodium yoelii infected mice, Elsevier: Biotechnology Advances: 310-320.

[3] Bandyopadhyay, S., Katare, O. P., \& Singh, B. (2012). Optimized self nanoemulsifying systems of ezetimibe with enhanced bioavailability potential using long chain and medium chain triglycerides, Colloids and Surfaces B: Biointerfaces, Vol. $\quad 100: 50-61$.

[4] Beg, S., Katare, O. P., \& Singh, B. (2017). Formulation by design approach for development of ultrafine self- nanoemulsifying systems of rosuvastatincalcium containing long-chain lipophiles for hyperlipidemia management, Colloids and Surfaces B: Biointerfaces, Vol. 159: 869-879.

[5] Dabhi, M. R., Limbani, M. D., Sheth, N. R. (2011). Preparation and In Vivo Evaluation of Self-Nanoemulsifying Drug Delivery Current Nanoscience, Vol. 7: $\quad 616-627$.

[6] Date, A. A., Desai, N., Dixit, R., Nagarsenkar, M. (2010). Self nanoemulsifying drug delivery systems: formulation insights applications and advances, Nanomedicine, Vol. 5: 1595- 1616.

[7] Gardouh, A. R., Nasef, A. M., Mostafa, Y., \& Gad, S. (2020). Design and evaluation of combined atorvastatin and ezetimibe optimized self- nano emulsifying drug delivery system, Journal of Drug Delivery Science and Technology, Vol. 60: 102093.

[8] Gupta, A., Sehgal, V., Mehan, S. (2011). Hyperlipidemia: An updated review, International Journal of Biopharmaceutics and toxicological Research, Vol. 1(1): 8189.

[9] Harikumar, K., Althaf, S. A., Kishore Kumar, B., Ramunaik, M., \& Suvarna, C. (2013). A Review on Hyperlipidemic, International Journal of Novel Trends in Pharmaceutical Sciences, Vol. 3(4): 69-80.

[10] Kasim, N.A.,Whitehouse, M., Ramachandran, C., Bermejo, M., Lennernäs, H., Hussain, A.S., Junginger, H.E., Stavchansky, S.A., Midha,K.K., Shah,V.P.,Amidon, G.L., (2004). Molecular properties of WHO essential drugs and provisional biopharmaceutical classification, Mol. Pharm., Vol. 1: 85-96.

[11] Kaur, G., Pankaj, C., and Harikumar, S. L. (2013). Formulation Development of SelfNanoemulsifying Drug Delivery System (SNEDDS) of Celecoxib for Improvement of Oral Bioavailability, Pharmacophore, $\quad$ Vol. 4, No. 4.

[12] Makadia, H. A., Bhatt, A. Y., Parmar, R. B., Paun, J. S., and Tank, H. M. (2013). SelfNano Emulsifying Drug Delivery System (SNEDDS): Future Aspect, Asian Journal of Pharmaceutical Research, Vol. 3, No. 1: 21-27.

[13] Martien, R., Adhyatmika., Irianto, I.D.K., Farida, V., Sari, D.P. (2012). Perkembangan Teknologi Nanopartikel sebagai Sistem Penghantaran Obat, Majalah Farmasi, Vol. $8(1)$.

[14] Negi, J. S. (2019). Nanolipid Materials for Drug Delivery Systems: A Comprehensive Review, Characterization and Biology of Nanomaterials for Drug Delivery: Nanoscience and Nanotechnology in Drug Delivery: 137-163. Pakki, E., Sumarheni. 
[15] Pouton, C. W. (2006). Formulation of poorly water-soluble drugs for oral administration: physicochemical and physiological issues and the lipid formulation classification system, Eur. J. Pharm. Sci., Vol. 29: 278- 287.

[16] Rowe, R. C., Sheskey, P. J., Quinn, M. E. (2009). Handbook of Pharmaceutical Excipients 6th Ed, Pharmaceutical Press, USA.

[17] Siaw, O. et al. (2016). Hypolipidemic potential of perillaldehyde-loaded selfnanoemulsifying delivery system in high-fat diet induced hyperlipidemic mice: Formulation, in vitro and in vivo evaluation, European Journal ofPharmaceutical Sciences, Vol. 85: 112-122.

[18] Singh, B., Bandopadhay, S., Kapil, R., Singh, R. \& Katare, O. P. (2009). SelfEmulsifying Drug Delivery System (SEDDS): Formulation Development, Characterization, and Applications, Critical Reviews in Therapeutic Drug Carrier

[19] Tripathi, C. B., Gupta, N., Kumar, P., Singh, A. K., Raj, V., Parashar, P., Singh, $\quad$ M., Kanoujia, J., Arya, M., Saraf, S. A., \& Saha, S. (2017). $\omega-3$ Fatty AcidSynergized Novel Nanoemulsifying System for Rosuvastatin Delivery: In Vitro and In Vivo $\quad$ Evaluation, AAPS PharmSciTech, $\quad$ Vol. 19(3): 1205- 1218.

[20] Villar, A. M. S., Naveros, B. C., Campmany, A. C. C., Trenchs, M. A., Rocabert, C. B., \& Bellowa, L. H. (2012). Design and optimization of self- nanoemulsifying drug delivery systems (SNEDDS) for enhanced dissolution of gemfibrozil, International Journal of Pharmaceutics, Vol. 431(1-2): 161-175.

[21] Wahyuningsih, I., dan Widyasari, P. (2015). Optimasi Perbandingan Tween 80 dan Polietilenglikol 400 pada Formula Self- Nanoemulsifying Drug Delivery System (SNEDDS) Minyak Biji Jinten Hitam, PHARMACY, Vol. 12, No.2. 